\title{
ASSESSMENT OF PUBLIC SAFE GROUNDWATER SOURCES IN BAUCHI STATE NIGERIA: A BASELINE STATUS FOR MONITORING PROGRESS TOWARDS SUSTAINABLE DEVELOPMENT GOAL 6
}

\author{
${ }^{* 1}$ Ndububa, $\mathbf{O}$. I. \\ ${ }^{*}$ Department of Civil Engineering, Federal University, Oye-Ekiti, Ekiti State, Nigeria.
}

*Corresponding Author's E-mail: ndububaoi@yahoo.com Phone: +2348038793929

\begin{abstract}
The performance status of access to safe water sources in a community is determined by the percentage of the population using domestic water sources that meet international standards. Nigeria achieved a total of about $67 \%$ of the population with access to safe water sources by 2015 at the end of the period of the Millennium Development Goals. Ensuring universal access to safe and affordable drinking water for all requires investment inadequate infrastructure, this requirement led to the investigation of facilities currently available in Bauchi State of Nigeria. A baseline survey was conducted in the State towards monitoring progress on development goals, the baseline survey covered safe water sources and health facilities in State. It was found that Dambam Local Government Area recorded the highest access of $60.6 \%$ of the population with access to safe water sources, $33.33 \%$ of the population in Bauchi Local Government Area has access to public safe water sources while the lowest access recorded 5.26\% in Toro Local Government Area. The functionality status of installed safe water sources in the State is currently low; Bauchi Local Government Area recorded a functionality status of $46 \%$ for the public motorized schemes and $66 \%$ functionality status for the handpump equipped boreholes. It was recommended that in working towards achieving Sustainable Development Goal number 6, massive repair and rehabilitation exercise is required to be carried out on nonfunctional water supply sources in the State to improve the access to safe water sources.
\end{abstract}

Keywords: motorized boreholes, hand-pumps, safe water sources, groundwater

LICENSE: This work by Open Journals Nigeria is licensed and published under the Creative Commons Attribution License 4.0 International License, which permits unrestricted use, distribution, and reproduction in any medium, provided this article is duly cited.

COPYRIGHT: The Author(s) completely retain the copyright of this published article.

OPEN ACCESS: The Author(s) approves that this article remains permanently online in the open access (OA) model.

QA: This Article is published in line with "COPE (Committee on Publication Ethics) and PIE (Publication Integrity \& Ethics)". 


\section{INTRODUCTION}

Nigeria's access to safe drinking water sources and acceptable sanitation practices contributes to global achievement on percentage population of people with access to safe water sources and adequate sanitation, national figures for Nigeria shows that only $67 \%$ of the population had access to at least basic improved drinking water sources (WHO, 2017). 300 million people without access to safe water sources worldwide, live in sub-Saharan Countries in Africa (UNICEF/WHO, 2015), as a result, a high percentage of the population without access to safe water sources are burdened with poor health based on the use of unprotected water sources such as rivers, streams, unprotected springs and unprotected hand dug wells. Many of these sources are found where open field defecation is practiced and flood-washed wastes affect the quality of water (FMWR, 2016).

Sustainable Development Goal (SDG) number 6 is to ensure availability and sustainable management of water and sanitation for all by the year 2030 (UNDP, 2018). Ensuring universal access to safe and affordable drinking water for all by 2030 requires investment in adequate infrastructure (UNDP, 2016). Preparedness for the achievement of the SDGs need to be supported by a series of elements including satisfactory mobilization and integrated management of resources (Wang and $\mathrm{Wu}, 2013$ ). Access to safe water is measured by the percentage number of people who have acceptable means of getting an adequate amount of water that is safe for drinking, washing, and essential household activities (FMWR, 2005). The level of service in accessing safe water sources is used to describe the quality of the service being provided to users (Deverill et al, 2002), the level of service and basic indicators for measuring access to safe water sources revolve around quality, distance and time indices (Skinner, 2009). Efforts to provide safe water will be useless if polluted water eventually reaches the end users due to poor handling, it is therefore very important to protect stored water from contamination (Skinner, 2009). A wide range of ecological and human crises results from inadequate access (Sowjanya and Sailaja, 2017), the proximity of the safe water source to the household plays a major role in quantities of water used, the importance of reducing distance of new water sources in close proximity to end users cannot be over emphasized (Carter et al, 1997).

Nigeria successfully participated in the Millennium Development Goals (MDGs) in striving to achieve the eight international development goals that were established at the Millennium Summit of the United Nations in 2000 (UN, 2000). Nigeria achieved a total access of about $67 \%$ of the population to safe water sources by 2015 (UNICEF/WHO, 2015). The 2015 status forms the baseline for Nigeria on working at the Sustainable Development goals.

\section{THE STUDY AREA}

Bauchi State, is located in the North-Eastern part of the Nigeria; this State was created on $3^{\text {rd }}$ of February 1976. The present Bauchi State's southern and northern limits are demarcated by latitudes $9^{\circ} 30^{\prime} \mathrm{N}$ and $12^{\circ} 30^{\prime} \mathrm{N}$ respectively, its western and eastern limits are bounded by longitudes $8^{\circ} 45^{\prime} \mathrm{E}$ and $11^{\circ} 0^{\prime} \mathrm{E}$ respectively, the State's total land area covers about 49,259 square kilometers (FMAWR, 2008). The state occupies a central location spatially among the north-east group of states in Nigeria as presented in Fig. 1. The rainy season months in the State are May to September, when humidity ranges from about 37 percent to 68 percent. Mean daily temperatures range from $29.2^{\circ} \mathrm{C}$ in July to October, about $11.7^{\circ} \mathrm{C}$ in November/December to February and $37.6^{\circ} \mathrm{C}$ from March to June of any year 
(FMWR, 2008). Bauchi state is one of the states in the Northern part of Nigeria that span two distinctive vegetation zones, namely, the Sudan Savannah and the Sahel Savannah.

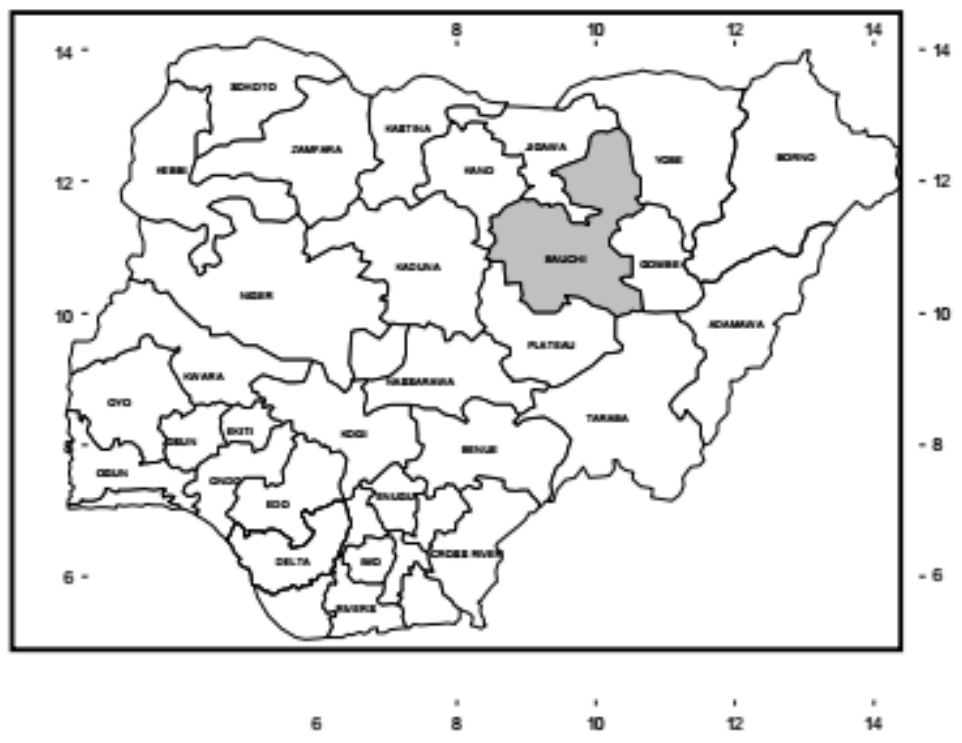

Figure 1: Map of Nigeria showing Bauchi State

Statement on research problem is based on analysing the status of the public safe water sources in Bauchi State in relation to the types of reported diseases in the State. Baseline data is required in any country to monitor progress of achieving results for sustainable water supply sources. Analysis of the information is to be used in taking informed decisions towards meeting the goal number 6 of the Sustainable Development Goals and support the monitoring and evaluation of the progress towards achieving the SDG set goals.

\section{MATERIALS AND METHOD}

The experimental design for the research is based on collection of data via primary and secondary sources which were subjected to data analysis using standard equations.

The primary source of information was from:

1. The Federal Ministry of Water Resources that conducted a baseline survey which covered public supply of safe water and health facilities in State. Safe public water sources in the State were identified as motorized boreholes and handpump equipped boreholes, other sources of ground water supply include protected and unprotected hand dug wells which are not public sources of water supply therefore not included in the report. The Federal Ministry worked along with the:

2. Bauchi State Ministry of Water Resources

3. Bauchi State Water Board, which is the main Government establishment responsible for water supply in the State.

4. Bauchi State Rural Water Supply and Sanitation Agency, which is responsible for rural water supply and the provision of sanitation facilities in all parts of the state.

Secondary sources of information were obtained from books, journals, online materials, relevant documents and published related works. Relevant raw data obtained from the Federal Ministry of Water Resources were analyzed 
and presented using tables and descriptive statistical tools such as bar charts to determine relationship between the variables.

\section{DATA COLLECTION}

Types of data collected:

i. The attributes and functionality status of public water supply facilities.

ii. Reported cases of water related diseases from health institutions.

Data Analysis:

Determination of percentage water supplied to water demand water was carried out using the equation:

Total Safe Water available in $\mathrm{m}^{3} / \mathrm{day} \times 100 \%$

Total Water Demand in $\mathrm{m}^{3} /$ day

Total percentage public water supply coverage was determined by:

Percentage Service Coverage $=\sum(\mathrm{PT}) *[$ Average no of People per PT $]+\sum($ hbh $) *[$ Average no of People per hbh]) /Total population of the LGA

Where PT = public taps (10 public taps per motorized borehole); and hbh = hand pump boreholes (single outlet).

\section{THE DEFINITION OF TERMS}

For 'acceptable limits' of water demand and supply used in this report is based on the definition from the Federal Ministry of Water Resources' Water and Sanitation Policy (FMWR, 2005) and the World Health Organization (WHO, 2011) as follows:

Rural water supply is guaranteed minimum level of service 30 liters per capita per day within 250 meters of the community of 150 to 5,000 people, serving about 250-500 persons per water point. (FMWR, 2005).

Semi-urban (small towns) water supply represents settlements with population of between 5,000-20,000 with a fair measure of social infrastructure and some level of economic activity with minimum supply standard of 60 liters per capita per day with reticulation and limited or full house connections as determined by the beneficiaries / Government. (FMWR, 2005).

Urban water supply represents 120 liters per capita per day for urban areas with population greater than 20,000 inhabitants to be served by full reticulation and consumer premises connection (FMWR, 2005)

Basic service means a protected, year-round supply of 30 litres per capita per day in line with the 30 litres basic minimum utilized by international agencies preferably within 250 metres of the community and not exceeding 500 metres, serving about 250 persons per outlet. Higher levels of service are encouraged, but communities must pay for the added cost. (FMWR, 2005)

The WHO defines safe water as water having acceptable quality in terms of its physical, chemical, bacteriological parameters so that it can be safely used for drinking and cooking and no significant health risks occurs during the lifespan of the scheme from storage to end user (WHO, 2011). 


\section{RESULTS}

From the data obtained, information on names of all the 20 Local Government Areas (LGAs) of the State, the Population of each LGA (from 2006 National Population Census figure (NBS, 2007) and Ref. World Population Review (2018)), number of functional water sources in each LGA, the estimated water demandand calculated water supplied to each LGA and percentage ratio of water supplied to water demand in each LGA is presented in table 1. Types and number of reported water related diseases in LGAs for Baseline year are presented in table 2. Figure 1 shows the results obtained for the percentage functionality status of public ground water facilities while figure 2 give a graphical presentation of the percentage water supplied in the LGAs and the percentage number of reported cases of water related diseases.

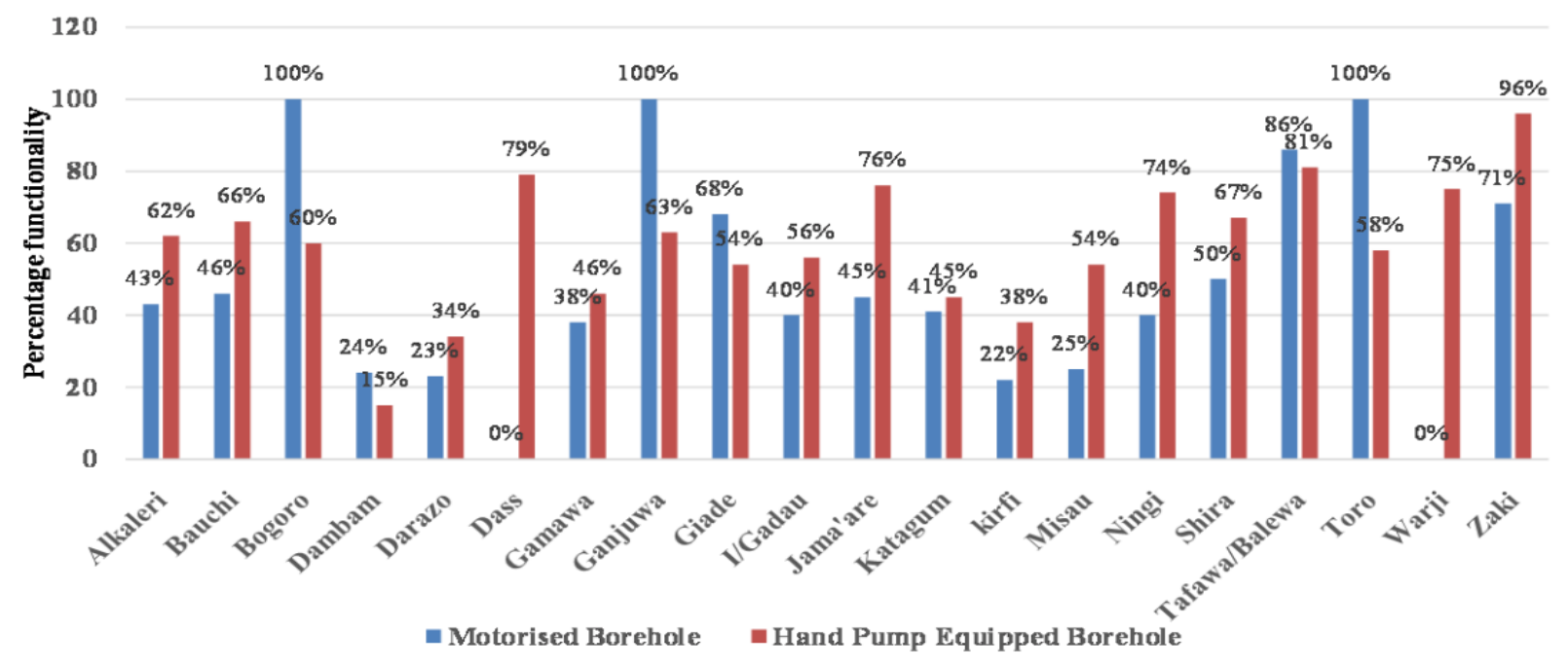

Figure 1: Percentage Functionality Status of Public Ground Water Supply Facilities

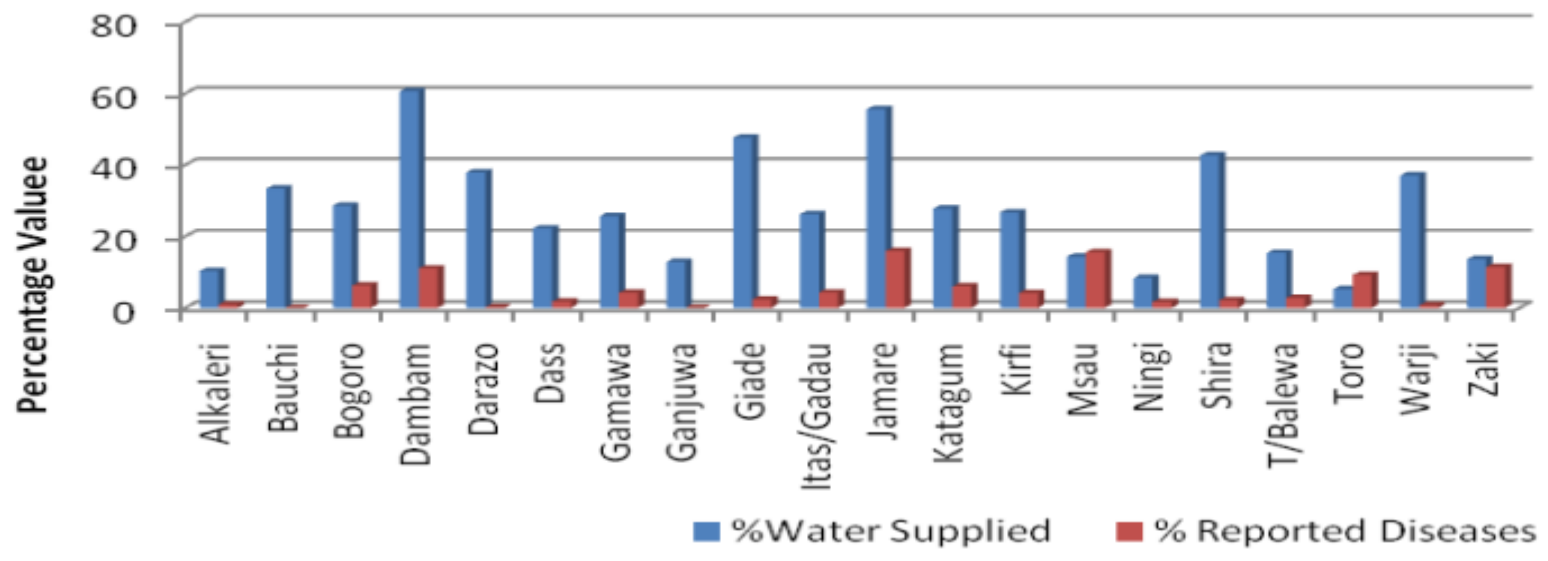

Figure 2: Water Supplied and \% Reported Diseases in LGAs 
Table 1: Names, Population of Local Government Areas, Number of Functional Water Sources and Estimated Water Demand

\begin{tabular}{|c|c|c|c|c|c|c|c|c|c|}
\hline S/No & $\begin{array}{l}\text { Local } \\
\text { Government } \\
\text { Area (LGA) }\end{array}$ & Population & $\begin{array}{l}\text { Total Number } \\
\text { Motorized } \\
\text { Borehole } \\
\text { Schemes }\end{array}$ & $\begin{array}{l}\text { Number } \\
\text { Functional } \\
\text { Motorized } \\
\text { Borehole } \\
\text { Schemes }\end{array}$ & $\begin{array}{l}\text { Total } \\
\text { Number of } \\
\text { Handpump } \\
\text { Equipped } \\
\text { Boreholes }\end{array}$ & $\begin{array}{l}\text { Number } \\
\text { Functional } \\
\text { Handpump } \\
\text { Equipped } \\
\text { Boreholes }\end{array}$ & $\begin{array}{l}\text { Estimated } \\
\text { Water } \\
\text { Demand } \\
\left(\mathrm{m}^{3} / \mathbf{d}\right)\end{array}$ & $\begin{array}{l}\text { Estimated } \\
\text { Output/ } \\
\text { Supplied } \\
\left(\mathrm{m}^{3} / \mathbf{d}\right)\end{array}$ & $\begin{array}{l}\text { \% Ratio of } \\
\text { Public Water } \\
\text { Supplied against } \\
\text { Demand }\end{array}$ \\
\hline 1 & Alkaleri & 324354 & 7 & 3 & 21 & 13 & 12650 & 1297 & 10.26 \\
\hline 2 & Bauchi & 662065 & 13 & 6 & 94 & 62 & 79448 & 26483 & 33.33 \\
\hline 3 & Bogoro & 98192 & 2 & 2 & 55 & 33 & 4124 & 1178 & 28.57 \\
\hline 4 & Dambam & 153103 & 41 & 10 & 48 & 7 & 10105 & 6124 & 60.60 \\
\hline 5 & Darazo & 303893 & 61 & 14 & 38 & 13 & 20057 & 7597 & 37.88 \\
\hline 6 & Dass & 93268 & 0 & 0 & 47 & 37 & 4197 & 933 & 22.22 \\
\hline 7 & Gamawa & 336148 & 16 & 6 & 61 & 28 & 13110 & 3361 & 25.64 \\
\hline 8 & Ganjuwa & 268514 & 6 & 6 & 38 & 24 & 10472 & 1343 & 12.82 \\
\hline 9 & Giade & 171114 & 19 & 13 & 41 & 22 & 7187 & 3422 & 47.62 \\
\hline 10 & Itas/Gadau & 251727 & 25 & 10 & 18 & 10 & 10572 & 2769 & 26.19 \\
\hline 11 & Jama'are & 130652 & 29 & 13 & 70 & 53 & 9407 & 5226 & 55.56 \\
\hline 12 & Katagum & 361832 & 41 & 17 & 97 & 44 & 26052 & 7237 & 27.78 \\
\hline 13 & Kirfi & 153978 & 9 & 2 & 48 & 18 & 6929 & 1848 & 26.67 \\
\hline 14 & Misau & 253463 & 8 & 2 & 41 & 22 & 10645 & 1521 & 14.29 \\
\hline 15 & Ningi & 410203 & 5 & 2 & 34 & 25 & 24612 & 2051 & 8.33 \\
\hline 16 & Shira & 300183 & 34 & 17 & 46 & 31 & 11257 & 4803 & 42.67 \\
\hline 17 & TafawaBalewa & 234529 & 7 & 6 & 31 & 25 & 9147 & 1407 & 15.38 \\
\hline 18 & Toro & 388148 & 5 & 5 & 45 & 26 & 22124 & 1164 & 5.26 \\
\hline 19 & Warji & 109161 & 2 & 0 & 72 & 54 & 4421 & 1637 & 37.04 \\
\hline \multirow[t]{2}{*}{20} & Zaki & 304052 & 24 & 17 & 25 & 24 & 22348 & 3041 & 13.61 \\
\hline & Total Figures & 5308579 & 354 & 151 & 970 & 571 & 318864 & & 27.59 \\
\hline
\end{tabular}

Table 2: Types and Number of Reported Cases of Water Related Diseases in Local Government Areas for Baseline year

\begin{tabular}{|c|c|c|c|c|c|c|c|c|c|c|c|c|c|c|}
\hline $\mathbf{S} / \mathbf{N}$ & LGA & 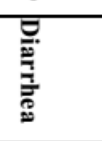 & 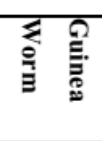 & 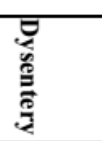 & 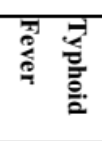 & 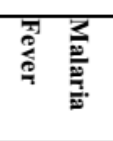 & 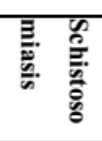 & 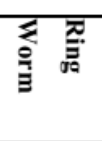 & $\frac{2}{\frac{2}{3}}$ & 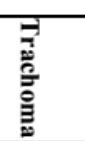 & 恶 & 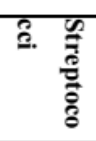 & 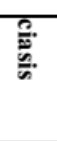 & 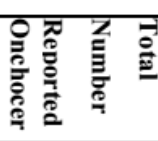 \\
\hline 1 & ALKALERI & 307 & 0 & 204 & 106 & 724 & 0 & 6 & 0 & 0 & 0 & 0 & 0 & 1449 \\
\hline 2 & BAUCHI & 5,091 & 0 & 2,570 & 2,084 & 473,450 & 74 & 79 & 470 & 21 & 9 & 51 & 0 & 484380 \\
\hline 3 & BOGORO & 2,364 & 0 & 1,322 & 468 & 5,151 & 285 & 46 & 47 & 83 & 14 & 15 & 0 & 9890 \\
\hline 4 & DAMBAN & 3,444 & 0 & 1,925 & 655 & 10,838 & 80 & 7 & 4 & 207 & 0 & 0 & 0 & 17534 \\
\hline 5 & DAZARO & 47 & 0 & 45 & 31 & 146 & 3 & 7 & 19 & 1 & 6 & 0 & 9 & 336 \\
\hline 6 & DASS & 512 & 0 & 391 & 326 & 999 & 62 & 9 & 141 & 17 & 5 & 215 & 14 & 2720 \\
\hline 7 & GAMAWA & 1,250 & 0 & 1,291 & 438 & 3,554 & 119 & 24 & 0 & 0 & 0 & 0 & 0 & 6706 \\
\hline 8 & GANJUWA & & & & & & & & & & & & & \\
\hline 9 & GIADE & 763 & 0 & 532 & 233 & 1,716 & 65 & 31 & 52 & 81 & 72 & 4 & 6 & 3674 \\
\hline 10 & ITAS/GADAU & 1,406 & 0 & 690 & 206 & 4,025 & 20 & 25 & 128 & 55 & 2 & 0 & 0 & 6809 \\
\hline 11 & JAMARE & 2,692 & 0 & 2,284 & 214 & 18,801 & 0 & 153 & 270 & 48 & 0 & 0 & 0 & 25291 \\
\hline 12 & KATAGUM & 1,672 & 0 & 941 & 577 & 4,002 & 64 & 109 & 1,836 & 78 & 144 & 26 & 9 & 9570 \\
\hline 13 & KIRFI & 2,012 & 0 & 836 & 434 & 3,201 & 14 & 7 & 4 & 43 & 6 & 22 & 0 & 6605 \\
\hline 14 & MISAU & 6,478 & 0 & 4,228 & 705 & 12,645 & 63 & 47 & 129 & 112 & 12 & 0 & 0 & 24711 \\
\hline 15 & NINGI & 369 & 0 & 347 & 671 & 674 & 0 & 38 & 453 & 0 & 0 & 0 & 14 & 2593 \\
\hline 16 & SHIRA & 846 & 0 & 447 & 145 & 1,449 & 11 & 10 & 89 & 44 & 136 & 0 & 83 & 3394 \\
\hline 17 & T/BALEWA & 495 & 0 & 535 & 728 & 1,472 & 113 & 94 & 557 & 57 & 75 & 47 & 85 & 4360 \\
\hline 18 & TORO & 1,702 & 0 & 1,458 & 1,002 & 9,677 & 50 & 175 & 122 & 5 & 18 & 17 & 14 & 14594 \\
\hline 19 & WARJI & 250 & 0 & 126 & 120 & 410 & 18 & 19 & 92 & 37 & 7 & 15 & 3 & 1131 \\
\hline \multirow[t]{2}{*}{20} & ZAKI & 2,248 & 0 & 1,728 & 1,941 & 3,844 & 0 & 0 & 4,807 & 1,812 & 344 & 490 & 684 & 17898 \\
\hline & TOTAL & 33,948 & 0 & 21,900 & 11,084 & 556,778 & 1,041 & 886 & 9,220 & 2,701 & 850 & 902 & 921 & \\
\hline
\end{tabular}

Table 2: Types and Number of Reported Cases of Water Related Diseases in Local Government Areas for Baseline year 


\section{ANALYSIS AND DISCUSSION OF RESULTS}

Table 1 shows that the total population of Bauchi State as at 2015 is estimated at 5,308,579 (Five million, Three Hundred and Eight Thousand, Five Hundred and Seventy-Nine) people. The type and functionality status of the public water supply facilities in the State are also presented in table 1. The table shows that Darazo has the highest number of installed motorized schemes in the state with 61 installed schemes, however only 14 are functional, Katagum has the highest number of handpump equipped boreholes with only 44 functional sources out of the 97 installed. The status at any point in time of installed water sources will directly affect the safe water supply status of the State. Analysis of Nigeria's progress during the implementation of the Millennium Goals showed that installed capacity of safe water schemes operated below optimum due to high number of non-functional water sources. (Ndububa and Ndububa (2016). The most critical outcome of the analysis on the percentage values of water supplied to water demand in the LGAs shows that Dambam LGA has the highest value of $60.60 \%$ while Ningi and Toro LGAs have values as low as $8.33 \%$ and $5.26 \%$ respectively, an average of $27.59 \%$ value of water supplied in the State against demand. This result shows that there is no LGA that has fully met its water demand. Meeting the Sustainable Development Goal number 6 on access to clean water for all by 2030 requires provision of safe water sources across all LGAs in Bauchi State.

Use of safe water sources is not only based on functionality, research shows that 0.5 to $50 \mathrm{mg} / \mathrm{l}$ of iron content is found in natural water bodies and Zinc is found to occur naturally in soils with estimated content between $1-300 \mathrm{mg} / \mathrm{Kg}$ (WHO, 2003), high levels of chemical compounds also impact on the use of installed facilities, correct application are now used effectively in micropollutant removal (Zavala and Lara, 2018), also poor water quality impact negatively on the health (Hemangi and Hitesh, 2017), it is paramount therefore that the groundwater's capacity to maintain its natural assimilative properties is protected (Chiejine, 2016), functionality must be coupled with safety.

Table 2 presents the numbers and different types of water related diseases reported in the State, malaria fever recorded the highest incidence in all the Local Government Areas while guinea worm disease was not recorded in any of the Local Government Areas. Risks of groundwater contamination which exists governed by the vulnerability and presence of contaminants in water also contribute to incidence of water related diseases (Sharadqah, 2017). In some countries groundwater has been contaminated by the very bad practice of pumping wastes down disused bores (Sinton, 2001) leading to occurrence of water related diseases in such areas.The sum of all incidents of specified water related diseases reported from all health institutions in LGAs are also presented in table 2. The table shows the number of times diseases are reported, Bauchi town has the highest number of reported cases of all reported diseases, this can be directly related to water quality, which is indicative pollution levels which will directly impact on the oxygen content in water (Ogbonna and Chinomso, 2010)

Although figure 1 shows that Bogoro, Ganjuwa and Toro LGAs recorded 100\% functionality of installed water sources, values presented in table 1 shows that these LGAs have limited number of motorized water supply facilities. Figure 2 gives an analysis of the comparison of the percentage water supplied in LGAs and percentage number of reported cases of water related diseases. The chart shows an inverse relationship between availability of 
safe water sources and incidence of water related diseases in most of the LGAs, the installed safe water sources have high impact on reduction of water related diseases.

\section{CONCLUSION}

The following conclusions are made from the analysis of results obtained from data:

1. The State recorded $27.59 \%$ of water demand met, with access to safe water sources at $5.26 \%$ of the demand in Toro Local Government Area.

2. The functionality status of installed safe water sources in the State is currently low, Bauchi Local Government Area recorded a functionality status of $46 \%$ for the motorized schemes and $66 \%$ functionality status for the handpump equipped boreholes.

3. 17 out of the 20 Local Government Areas has percentage functionality status of the handpump equipped boreholes with values greater than $50 \%$ while only 7 of the 20 LGAs had percentage functionality of $50 \%$ and above for the motorized schemes.

4. Incidence of water related diseases in the State is highly impacted by the availability of safe water sources.

\section{RECOMMENDATIONS}

1. Implementation of activities to increase access to public safe water sources has to prioritize interventions in Toro, Ningi, Alkaleri, Ganjuwa and Misau Local Government Areas that show very low access to safe water sources.

2. In working towards achieving the Sustainable Development Goal number 6, on access to clean water for all by 2030 , massive repair and rehabilitation exercise is required to be carried out on non-functional water supply sources in the State to improve the access to safe water sources.

3. Regulatory bodies should be empowered to support the private sector/ individuals willing to engage in providing safe water sources in the State. Provision for revision of polices have been found to be significant in achieving results.

4. Ownership of installed safe water facilities should be encouraged by involving communities from the planning stages of new water facilities.

5. Managing and maintaining an environment in which community members participate in water supply projects will efficiently achieve desired outcome.

\section{ACKNOWLEDGEMENT}

This is to acknowledge that data collection from the field work was led by the Federal Ministry of Water Resources, Abuja, Nigeria. 


\section{REFERENCES}

Abdulazeez, Q. M., Jami, M. S. \&Iam, M. Z. (2016). Effective Sludge Dewatering Using Moringa Olefera Seed Extract Combined with Aluminium Sulfate. ARPN Journal of Engineering and Applied Sciences. 11(1). Pp $372-380$

Carter R C, Tyrrel S F \&Howsam P. (1997). The impact and sustainability of water and sanitation programmes in developing countries, Journal of the Chartered Institution of Water and Environmental Management. 13: 292-296.

Chiejine, C. M., Igboanugo, A.C. and Ezemonye, L.I.N. (2016). Diverse Approaches toModelling the Assimilative Capacity of a Polluted Water Body. Nigerian Journal of Technology (NIJOTECH). 35 (1): 196-209.

Deverill, P., Bibby, S., Wedgwood, A., \&Smout, S. (2002). Designing Water Supply andSanitation Projects to meet Demand in Rural and Peri-urban Communities. WEDC publications, Leicestershire, United Kingdom, LE11 3TU UK.

Federal Ministry of Water Resources (FMWR). (2005). National Water Sanitation Policy. Federal Republic of Nigeria.

Federal Ministry of Agriculture and Water Resources (FMAWR). (2008). National WaterSupply and Sanitation Baseline Survey. Federal Government of Nigeria (Unpublished Survey).

Federal Ministry of Water Resources (FMWR) (2016). Making Nigeria Open Defecation Free by 2025 - A

National Road Map. Federal Ministry of Water Resources, Nigeria with support from European Union, UKAid and UNICEF Nigeria. https://www.unicef.org/nigeria

Hemangi, D \& Hitesh, D. (2017). A Green Water Technology: Groundwater Quality Investigation, Treatment with Natural Polyelectrolyte'. International Journal of Applied Environmental Sciences. 12(5). pp 755-772.

National Bureau of Statistics (NBS). (2007). Federal Republic of Nigeria. 2006 Population Census Figures" http://www.nigerianstat.gov.ng

Ndububa, O.I. and Ndububa, E. E. (2016). Millennium Development Goals (Goal 7, Target7c) in Nigeria: Need for a Coordinated Approach to Fast Track Infrastructural Development in the Water and Sanitation Sector. NSE Technical Transactions. Journal of the Nigerian Society of Engineers. 50 (1): pp 54- 69.

Ogbonna, J. F. and Chinomso, A. A. (2010). Determination of the Concentration of Ammonia that could have Lethal Effect on Fish Pond. ARPN Journal ofEngineering and Applied Sciences. 5(2). Pp 1-5

Sharadqah, S. (2017). Contamination Risk Evaluation of Groundwater in the Canton of Portoviewo-Ecuador, using Susceptibility Index and two Intrinsic Vulnerability Models'. American Journal of Environmental Sciences, 13(1). Pp 65-76

Sinton L. (2011). A Guide to Groundwater Sampling Techniques. National Water and Soil Conservation Authority, USA. Water and Soil Misc. Publication No. 99.

Skinner, B. (2009). Small Scale Water Supply 'A Review of Technologies. Practical Action Publishing Ltd”. Warwickshire, CV23, 9QZ, United Kingdom.

Skinner, B. (2009). Water and Environmental Sanitation - A Postgraduate Module. Loughborough University, Leicestershire. 
Sowjanya, P. and Sailaja, B.B.V. (2017). Geochemical Impact Assessment of GroundwaterQuality Along a Coastal District of Andhra Pradesh, India. Nature Environment and Pollution Techology. 16(3): 805 - 811.

UNDP (United Nations Development Programme). (2018). Retrieved September 20, 2018, from Sustainable

Development Goals. www.undp.org

United Nations. UN. (2000). The United Nations Report on the Millennium Development Goals. www.un.org/millenniumgoals

United Nations Children's Fund/ World Health Organization (UNICEF/WHO). (2015). Joint Monitoring Programme ((JMP) Report': Progress on Sanitation and Drinking Water Update and MDG Assessment. World Health Organization, Geneva, Switzerland.

Wang, X. H. And Wu, W. (2013). “A Review of Environmental Management Systems in Global Defence Sectors”. American Journal of Environmental Science Vol. 9 Issue 2, pp164-181 doi:10.3844/ajessp

World Health Organization (WHO). (2003). Zinc in Drinking Water - Background document for development of WHO guidelines for Drinking Water Quality" World Health Organization. Geneva, Switzerland who.int/water_sanitation_health.

World Health Organization (WHO). (2011). Guidelines for Drinking Water Quality. Third Edition. World Health Organization. Geneva, Switzerlandwho.int/water_sanitation_health.

World Health Organization (WHO) (2017). “Definition of Indicators” www.who.int/water_sanitation_health.

World Health Organization (WHO) (2017). "Simple Pit Latrines” Fact Sheet 3.4 http://www.who.int/water_sanitation_health/hygiene/emergencies/fs3_4.pdf.

World Population Review (2018). Nigeria’s Population (Demographic, Maps, Graphs). World Population Review. Www.worldpopulationreview.com

Zavala, M.A. L. and Lara, C.R.J. (2018). Degradation of Paracetamol and Its OxidationProducts in Surface Water by Electrochemical Oxidation. Environmental Engineering Science. 35(11). doi.org/10.1089/ees.2018.0023 